\title{
The Effects of Different Treatment Modalities on the Disease Course and Survival in Patients with Hepatocellular Cancer
}

\author{
Sahin LACIN ${ }^{1}$, Yusuf KARAKAS ${ }^{2}$, Omer DIZDAR ${ }^{2}$, Saadettin KILICKAP ${ }^{2}$, Manal M. HASSAN ${ }^{3}$, \\ Lianchun $\mathrm{XIAO}^{4}$, Ahmed O. KASEB ${ }^{5}$, Suayib YALCIN ${ }^{2}$ \\ ${ }^{1}$ Yeditepe University Faculty of Medicine, Department of Medical Oncology, Istanbul, Turkey \\ ${ }^{2}$ Hacettepe University Cancer Institute, Department of Medical Oncology, Ankara, Turkey \\ ${ }^{3}$ University of Texas, MD Anderson Cancer Center, Department of Epidemiology, Houston, USA \\ ${ }^{4}$ University of Texas, MD Anderson Cancer Center, Department of Biostatistics, Houston, USA \\ ${ }^{5}$ University of Texas, MD Anderson Cancer Center, Department of Gastrointestinal Medical Oncology, Houston, USA
}

\begin{abstract}
The overall survival rate of patients with hepatocellular carcinoma (HCC) is still poor, and development of innovative therapy modalities is of crucial importance. We aimed to evaluate the efficacy of available treatment modalities and investigate their impact on survival. Patients with HCC were included to the study. Disease stages were determined according to the most commonly used classification systems. Treatment modalities for patients were determined as local ablative, local palliative, surgery, systemic cytotoxic treatment, tyrosine kinase inhibitors, and best supportive care (BSC).Among 100 patients, 81 were men and 19 were women, the median age was 64. According to the Barcelona Clinic Liver Cancer staging system (BCLC), $1 \%$ of the patients were at very early stage, $16.3 \%$ early-stage, 22.4\% intermediate-stage, 56.1\% advanced-stage, and 4.1\% was at the terminal-stage. We observed significant difference with regards to overall survival $(\mathrm{OS})$ rates among different disease stage $(\mathrm{p}<0.001)$. Portal vein tumor thrombosis (PVTT) was reported in 42 patients, and the OS rate of patients with PVTT was poor ( $p=0.001)$. Among the first-line treatments, 9 patients received local ablative therapy, 25 local palliative, 27 systemic cytotoxic, 12 tyrosine kinase inhibitors, 10 surgical resection, and 4 BSC. The difference with regards to OS ratios of treatment groups was significant $(p<0.0001)$. We observed differential impact of diverse treatment modalities on survival of HCC patients. The study also revealed importance of various factors such as tumor size, disease stage, serum alpha-fetoprotein level, hepatic function status, and tumor vascular invasion status on clinical outcome.
\end{abstract}

Keywords: Alpha-fetoprotein, Hepatocellular cancer, Local ablative treatment, Portal vein thrombosis, Tyrosine kinase inhibitor

\section{ÖZET}

\section{Hepatoselüler Kanserli Hastalarda Farklı Tedavi Yöntemlerinin Hastalık Seyri ve Sağkalım Üzerine Etkileri}

Hepatoselüler karsinom (HSK) hastaların genel sağkalım oranı düşük olmaya devam etmektedir ve etkin tedavi yöntemlerinin belirlenmesi çok önemlidir. Bu çalışma ile mevcut tedavi yöntemlerinin etkinliklerinin değerlendirilmesi ve hasta sağkalımı üzerine etkilerinin araştıııması amaçlandı. Çalışmaya HSK tanılı hastalar dahil edildi. Hastalık evreleri en sık kullanılan sınılandırma sistemlerine göre belirlendi. HSK hastaları için kullanılan tedaviler lokal ablatif, lokal palyatif, cerrahi rezeksiyon, sistemik sitotoksik tedavi, tirozin kinaz inhibitörleri ve destek tedavisi olarak belirlenmiștir.Toplam 100 hastanın 81'i erkek, 19'u kadın, ortanca yaş 64 idi. Barselona Klinik Karaciğer Kanseri evreleme sistemi'ne (BCLC) göre hastaların \%1'i çok erken,\% 16,3'ü erken evrede, \%22.4'ü orta evre, \%56,1'i ileri evre ve hastaların \%4.1'i son evredeydi. Hastaların evrelerinde genel sağkalım (OS) oranları arasında anlamlı fark gözlendi ( $p<$ 0.001). Hastaların 42'sinde portal ven tümör trombozu (PVTT) rapor edildi ve PVTT'li hastaların OS anlamlı olarak kısa idi ( $p=0.001)$. İlk basamak tedavisi olarak 9 hastaya lokal ablatif tedavi, 25 lokal palyatif, 27 sistemik sitotoksik, 12 tirozin kinaz inhibitör tedavisi, 10 cerrahi rezeksiyon ve 4 destek tedavisi ile takip edildi. Tedavi gruplarının OS'leri arasındaki fark anlamlıydı ( $p<0.0001)$. Sonuç olarak illk basamak tedavi yöntemlerinin HSK hastalarının sağkalımı üzerindeki anlamlı farklarını gözlemledik. Ayrıca bu çalışma tümör boyutu, hastalık evresi, serum alfa-fetoprotein düzeyi, karaciğer fonksiyon durumu ve tümör vasküler invazyon durumu gibi faktörlerin sağkalım süreleri üzerindeki anlamlı etkilerini belirlemiştir.

Anahtar Kelimeler: Alfa-fetoprotein, Hepatoselüler kanser, Lokal ablatif tedavi, Portal ven trombozu, Tirozin kinaz inhibitörü 


\section{INTRODUCTION}

Despite significant improvement observed over decades in clinical diagnosis and management of the disease, the survival rate of patients with hepatocellular carcinoma (HCC) is still poor; the five-year overall survival rate remains around 10 to $15 \% .^{1}$ After lung, colorectal, and stomach cancer, HCC is the fourth leading cause of cancer death and the incidence of HCC is increasing worldwide. ${ }^{2}$ HCC can be classified if the disease originates from a cirrhotic and non-cirrhotic liver parenchyma. Classification, prognosis evaluation and therapy recommendations for patients with or without liver cirrhosis are crucial and therapeutic approaches are tailored according to diverse factors. ${ }^{3}$ Therefore, HCC treatment should be based on multidisciplinary approach, and patient selection and the type of treatment should be determined in comprehensive and experienced cancer centers. Different treatment modalities for hepatocellular carcinoma (HCC) are implemented by different medical specialties which include surgery, radiation oncology, medical oncology, nuclear medicine, and interventional radiology. There is a great need for classification systems where liver function status, disease stage, and patient performance status are evaluated effectively. Unfortunately, there is no globally accepted classification system yet, and each staging system may have certain limitations. The Barcelona Clinic Liver Cancer (BCLC) staging system is one of the most commonly used classification systems for HCC patients and based on this staging system different treatment modalities for the disease have been established. ${ }^{4,5}$ In this context, according to HCC management guidelines and the BCLC classification system, liver targeted or systemic therapies are preferred in patients who have advanced disease but limited to the liver or have metastatic disease. On the other hand, patients who initially have early-stage (0 or A) according to the BCLC are considered as suitable for potentially curative approaches such as local ablation (radiofrequency ablation (RFA), percutaneous ethanol injection (PEI), microwave ablation (MWA), etc.), resection, and orthotopic liver transplantation (OLT), these patients constitute around $30 \%$ of patients with HCC. ${ }^{4,6-8}$ Additionally, for patients with the BCLC stage B (intermediate stage), transarte- rial chemoembolization (TACE) is embraced as a standard of care, and this treatment modality results in around $15-55 \%$ partial response (PR) and up to 20 months median survival. ${ }^{9-12}$ Finally, for patients with unresectable, advanced disease (BCLC stage C), tyrosine kinase inhibitors (TKIs) are the standard treatments rather than conventional cytotoxic systemic therapy, and terminal-stage patients are followed up with best supportive care (BSC). ${ }^{13-}$ ${ }^{15}$ In this study, we aimed to analyze the outcome of our patients with HCC who treated with diverse treatment modalities based on by the BCLC classification system.

\section{PATIENTS AND METHODS}

\section{Patients}

The patients who diagnosed with HCC between January 2007 to October 2017 and whose data were contained within a prospectively maintained at the Cancer Institute were included. The diagnosis of HCC was determined as having proven pathological tissue findings or meeting the radiological criteria of the American Association of the Study of Liver Disease (AASLD). The radiological diagnosis of HCC was based on the typical hallmark of HCC (hypervascular in the arterial phase with washout in the portal venous or delayed phases) in imaging techniques that obtained by 4-phase multidetector CT scan or dynamic contrast-enhanced MRI. Other eligibility criteria were patients aged 18 years or older who had any disease stage of the BCLC, any level of serum $\alpha$-fetoprotein concentrations, adequate hematological and biochemical parameters. Patients were excluded if they had mixed hepatocellular and cholangiocellular carcinomas. The Child-Turcotte-Pugh (CTP) score of the patients was assessed for all patients based on laboratory values and clinical findings including cirrhosis like ascites and hepatic encephalopathy, and patients' disease stages were classified according to the BCLC staging system. All treatment decisions of patients had been discussed in the interdisciplinary tumor boards, and suitable treatment modalities for each patient have been recommended based on the most commonly used guidelines. The treatment modalities that include RFA, MWA, TACE, TARE, surgery, systemic therapy (cytotoxic systemic treatment or tyrosine kinase inhibitors), 
and best supportive care (BSC) were included as study variables, and the survival rates of these treatment groups were calculated. The laboratory parameters of patients that include ALT, AST, ALP, GGT, LDH, and serum AFP levels were obtained. Also, according to a cutoff value of the serum AFP level that defined by trials, patients divided into two groups. ${ }^{16}$

\section{Ethical Aspects}

The study was designed and conducted following the Helsinki declaration. Approval of the study was obtained from the Ethics Committee of the cancer institute.

\section{Assessment of Survival Outcomes}

The overall survival (OS) estimate is defined as the time from diagnosis to time of death. For patients whose complete follow-up data were not available, data on survival was censored at the time of the last documented contact.

\section{Statistical Analysis}

Differences in patient characteristics were compared between those receiving different treatment modalities for hepatocellular carcinoma. Categorical variables, number of patients and percentage of patients in each category were provided, and $X^{2}$ or the Fisher's exact test was used to test for statistical differences between the treatment groups. Survival rates were estimated by the Kaplan-Meier method and the log-rank test was used to compare OS rates between groups. Univariable and multivariable associations between survival and the covariates were investigated using the Cox proportional hazards model. Hazard ratios (HRs) with 95\% confidence intervals (CIs) were calculated. All tests were 2-sided with a significance level of 0.05 . Analyses were performed using SPSS version 22 statistical software (IBM Corporation, Somers, New York, USA).

\section{RESULTS}

We identified $100 \mathrm{HCC}$ patients who received one or more treatment modality or were followed up with the best supportive care (BSC) at our institu-

\begin{tabular}{|c|c|c|}
\hline & Number & $\%$ \\
\hline Total patients ( $\mathrm{n}$ ) & 100 & $100 \%$ \\
\hline Median age of all patients & $63(19-90)$ & $100 \%$ \\
\hline \multicolumn{3}{|l|}{ Median age } \\
\hline Female & $65(29-85)$ & $19 \%$ \\
\hline Male & $63(19-90)$ & $81 \%$ \\
\hline \multicolumn{3}{|l|}{ Gender } \\
\hline Female & 19 & $19 \%$ \\
\hline Male & 81 & $81 \%$ \\
\hline \multicolumn{3}{|l|}{ Cirrhosis } \\
\hline Yes & 59 & $19 \%$ \\
\hline No & 40 & $81 \%$ \\
\hline Not reported & 1 & $1 \%$ \\
\hline \multicolumn{3}{|l|}{ Serum AFP level groups } \\
\hline $\mathrm{AFP} \leq 400$ & 53 & $53 \%$ \\
\hline AFP $>400$ & 30 & $30 \%$ \\
\hline Not reported & 17 & $17 \%$ \\
\hline \multicolumn{3}{|l|}{ Portal vein invasion } \\
\hline No & 56 & $56 \%$ \\
\hline Yes & 42 & $42 \%$ \\
\hline Not reported & 2 & $2 \%$ \\
\hline \multicolumn{3}{|c|}{ Treatment groups as the first-line } \\
\hline RFA or MWA & 9 & $9 \%$ \\
\hline TACE or TARE & 25 & $25 \%$ \\
\hline Surgery & 10 & $10 \%$ \\
\hline Systemic cytotoxic & 27 & $27 \%$ \\
\hline Tyrosine Kinase & 12 & $12 \%$ \\
\hline BSC & 4 & $4 \%$ \\
\hline Hepatitis Infection & & \\
\hline HBV Positive & 41 & $41 \%$ \\
\hline Negative & 57 & $57 \%$ \\
\hline Not reported & 2 & $2 \%$ \\
\hline HCV Positive & 11 & $11 \%$ \\
\hline Negative & 87 & $87 \%$ \\
\hline Not reported & 2 & $2 \%$ \\
\hline The BCLC stages & & \\
\hline Very early & 1 & $1 \%$ \\
\hline Early & 16 & $16 \%$ \\
\hline Intermediate & 22 & $22 \%$ \\
\hline Advanced & 55 & $56 \%$ \\
\hline Terminal & 4 & $4 \%$ \\
\hline Not reported & 2 & $2 \%$ \\
\hline $\begin{array}{l}\text { Abbreviations: } \text { The } \mathrm{BCLC}=\text { Barce } \\
\text { AFP= } \alpha \text {-fetoprotein; } \mathrm{TACE}=\text { transa } \\
\mathrm{TARE}=\text { transarterial radioembolizat } \\
\mathrm{MWA}=\text { micro wave ablation; } \mathrm{TKI}= \\
\mathrm{BSC}=\text { best supportive care; } \mathrm{HBV}= \\
\mathrm{HCV}=\text { hepatitis } \mathrm{C} \text { virus }\end{array}$ & $\begin{array}{l}\text { a Clinic Liver } \\
\text { ial chemoemb } \\
\text { RFA= radiofre } \\
\text { osine kinase in } \\
\text { patitis B virus= }\end{array}$ & $\begin{array}{l}; \\
\text { y ablation } \\
\mathrm{s}=\end{array}$ \\
\hline
\end{tabular}




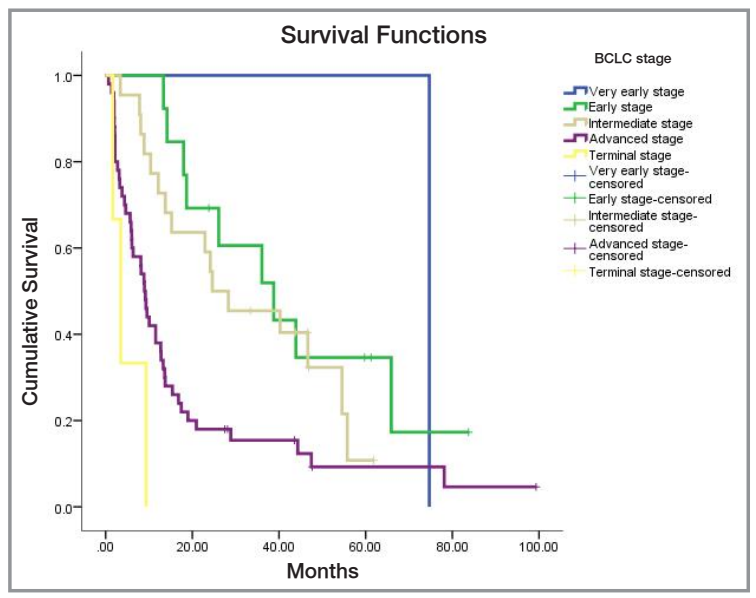

Figure 1. Kaplan-Meier curve illustrates the survival rates of HCC patients according to the BCLC staging system

tion. Nineteen (19\%) of the patients were female and $81(81 \%)$ were male; the median age of patients was 64 (range 19-90) years. Baseline demographic and clinical characteristics are listed in Table 1. The patients who were able to be classified according to the BCLC staging: 16 (16\%) HCC patients classified as BCLC early-stage, 22 (22\%) patients intermediate-stage, $55(55 \%)$ patients advancedstage, $4(4 \%)$ patients terminal-stage, and $1(1 \%)$ patient very-early stage, and disease stage of two (2\%) patients were not documented. There was a statistically significant difference between the median overall survival estimates of HCC patients according to BCLC stages: 74.6 months for patients with very early stage, 43.8 months for patients with early-stage, 24.6 months for patients with intermediate stage, 8.9 months for patients with advancedstage and 1.6 months for patients with the terminal stage $(\mathrm{p}<0.001)$ (Figure 1$)$. In terms of CTP classification, sixty-seven patients were CTP class A, 26 patients class B and 5 patients were class $C$. Among all patients, in terms of viral hepatitis, 41 of patients were HBV positive, 57 of patients were HBV negative, 11 of patients were HCV positive and 87 of remained patients were HCV negative. HBV infection was much more common almost 4 times than $\mathrm{HCV}$ infection. 40 patients were noncirrhotic and 59 were cirrhotic, and disease stage of one patient wasn't document in clinical record. Laboratory values were obtained, median LDH was 242 (76-1070) U/L, ALT was 35 (5-268) U/L,

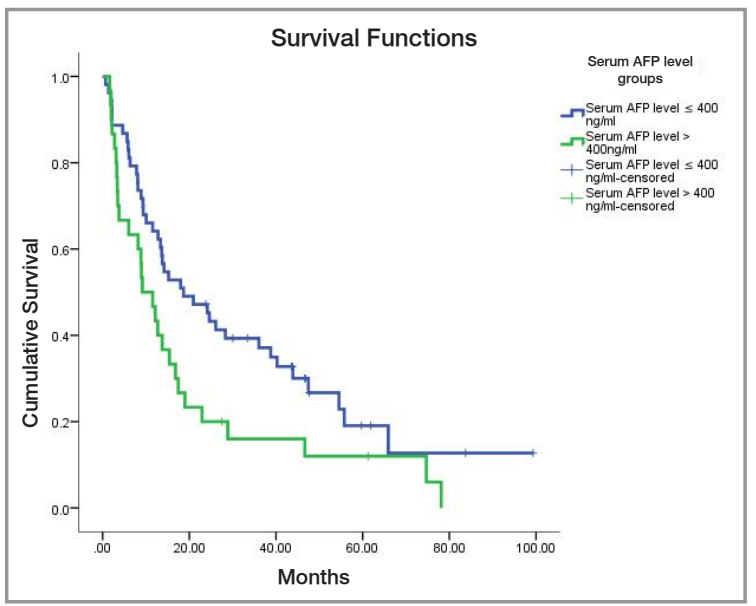

Figure 2. Kaplan-Meier curve illustrates the survival rates of HCC patients according to the AFP level

AST was 50 (8-512) U/L, ALP was 149 (41-1222) U/L, GGT was 132 (25-1719) U/L, AFP was 86 $(1.2-295.300) \mathrm{ng} / \mathrm{ml}$. The patients were divided into two groups according to serum AFP level of patients; group A was AFP level equal or less than $400 \mathrm{ng} / \mathrm{ml}$ and group B was AFP level more than $400 \mathrm{ng} / \mathrm{ml}$. There was a statistically significant difference between the median OS estimates of group A and group B. mOS rate was 18.6 and 9.1 months, respectively $(\mathrm{p}=0.032)$ ( Figure 2$)$. Fortytwo patients $(42 \%)$ had portal vein invasion while $56(56 \%)$ of patients didn't have any sign of portal vein invasion. Portal vein status for 2 patients was not documented. There was a statistically significant difference between OS estimates of patients with portal vein invasion compared to those without invasion, the median OS rate was 22.9 and 8.8 months, respectively $(\mathrm{p}=0.001)$ (Figure 3$)$. According to first-line treatment, a total of 87 were reported, 9 of the patients had RFA or MWA, 25 of the patients had TACE or TARE, 27 of the patients had systemic cytotoxic treatment, 12 of the patients had tyrosine kinase inhibitor treatment, 10 of the patients went under surgical resection as initial treatment of choice and 4 patients received BSC (Figure 4). There was a statistically significant difference between OS estimates of treatment groups, the median OS rate of patients underwent surgical resection was 65.9 months, 26 months for RFA or MWA treatment group, 18.9 months for TACE or TARE treatment group, 10 months for 


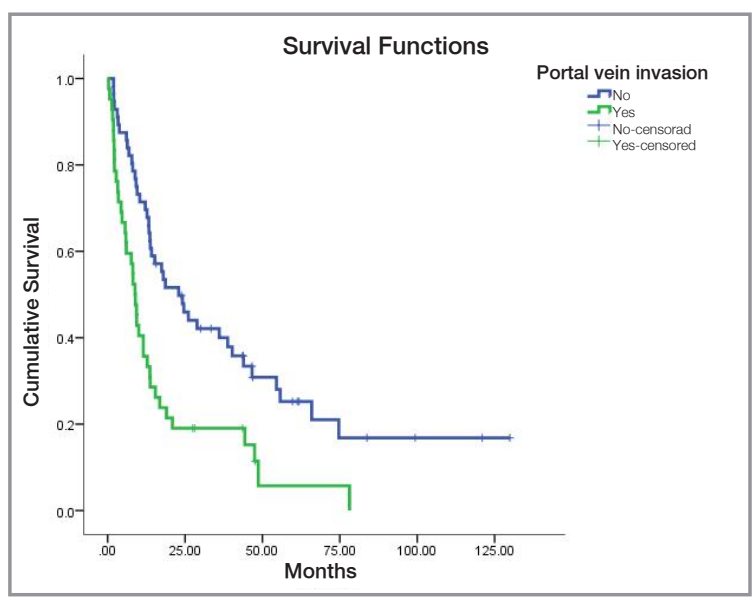

Figure 3. Kaplan-Meier curve illustrates the survival rates of HCC patients with or without portal vein invasion

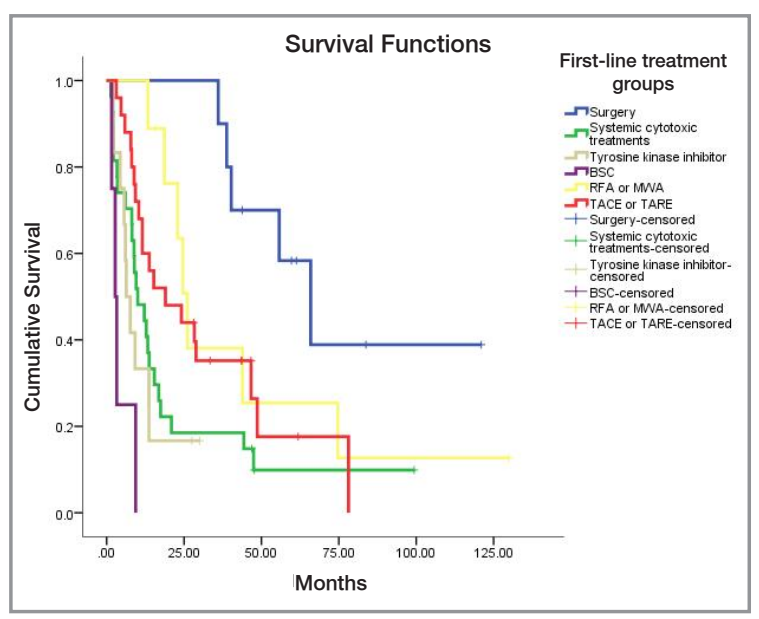

Figure 5. Kaplan-Meier curve illustrates the survival rates of HCC patients according to treatment groups

the systemic cytotoxic treatment group, 6.3 months for tyrosine kinase inhibitor group and 2.7 months for BSC group $(\mathrm{p}<0.0001)$ (Figure 5). The Cox regression analysis was done for the potential factors influencing clinical outcome. We identified gender, treatment modalities, portal vein invasion status, and serum AFP levels groups as factors associated with clinical outcome. We observed that some factors had significantly influenced overall survival when compared with each other; these factors that we identified were AFP level, portal vein invasion status, and treatment modalities. The patients with higher AFP levels or the portal vein invasion had a higher mortality rate than others. In the Cox regres-

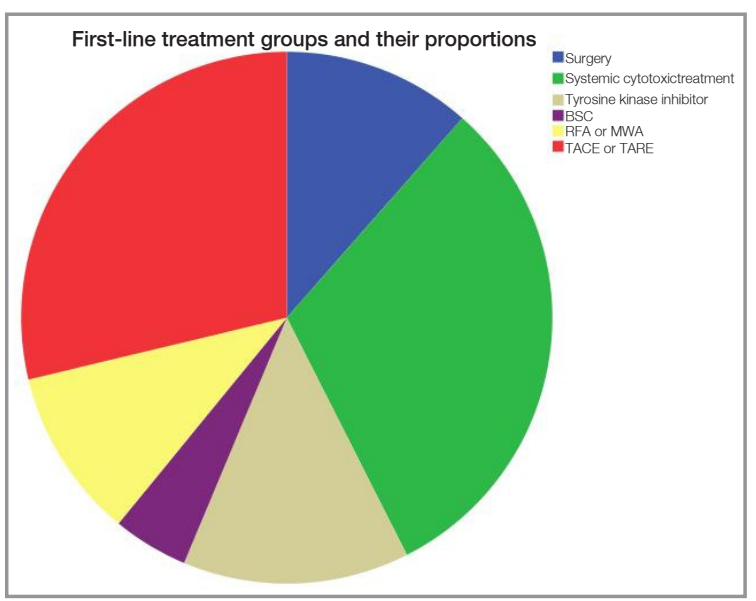

Figure 4. A pie graphic that includes the proportion of treatment groups

sion analysis, treatment modalities were compared with BSC. We observed that patients who underwent surgery or treated with RFA/MWA, TACE/ TARE, TKIs, and cytotoxic treatments had statistically significant lower mortality rates; gender didn't have a prognostic effect (Table 2). In terms of tumor size there was a significant difference between the treatment groups, which may have an impact on survival rates. Patients with larger tumor sizes tend to have shorter OS. The largest tumor size was $2.5 \mathrm{~cm}$ in the RFA or MWA treatment group, $8.3 \mathrm{~cm}$ in the TACE or TARE treatment group, $3.8 \mathrm{~cm}$ in the surgical treatment group, 10.4 $\mathrm{cm}$ in the systemic cytotoxic treatment group, 9.2 $\mathrm{cm}$ in the TKIs treatment group, and $14 \mathrm{~cm}$ in the BSC group $(\mathrm{p}<0.001)$ (Table 3).

\section{DISCUSSION}

Our retrospective study revealed that patients suitable for surgical resection or local ablative treatment had significant survival advantage, which was more in favor of surgical resection. The potential explanation for the survival advantage of surgical resection may be the selection criteria for the treatment approach. In general, patients with early disease stage and better liver function tend to be selected for surgical resection, and our approach for patient's selection was similar with previous studies. Unfortunately, surgical resection as a curative treatment method is chosen for patients 
Table 2. The Cox regression analysis of the factors and their effects on survival

\begin{tabular}{|c|c|c|}
\hline & Hazard Ratio $(95 \% \mathrm{Cl})^{*}$ & p value \\
\hline Serum AFP $>400$ vs. serum AFP $\leq 400$ & $1.69(1.042-2.76)$ & $0.034^{*}$ \\
\hline Male vs. Female & $0.89(0.49-1.59)$ & 0.69 \\
\hline Portal vein invasion positive vs. Negative & $2.09(1.31-3.33)$ & $0.002^{*}$ \\
\hline Surgery vs. Best supportive care & $0.04(0.10-0.15)$ & $<0.001^{*}$ \\
\hline Systemic cytotoxic treatment vs. Best supportive care & $0.20(0.06-0.62)$ & $0.005^{\star}$ \\
\hline Tyrosine Kinase Inhibitor vs. Best supportive care & $0.30(0.09-1.04)$ & $0.051^{*}$ \\
\hline RFA or MWA vs. Best supportive care & $0.08(0.02-0.32)$ & $<0.001^{*}$ \\
\hline TACE or TARE vs. Best supportive care & $0.12(0.04-0.38)$ & $<0.001^{*}$ \\
\hline
\end{tabular}

with limited disease, early-stage, and adequate liver function, and these patients constitute the minority of HCC patients. ${ }^{17,18}$ Another remarkable finding of our study was the importance of tumor diameter. The relationship between tumor size and poor prognostic factors has been reported in the literature, these factors are local invasion, portal vein tumor thrombosis (PVTT) and metastasis. ${ }^{19}$ In addition, patients with large tumors have an increased risk of tumor rupture and gastrointestinal bleeding, and treatment options are relatively limited. Our study reported tumor size as an independent prognostic factor for the survival of HCC patients.

The BCLC classification is one of the most commonly used system for the staging and management of HCC patients. Also, the BCLC classification system has been approved by the majority of popular guidelines such as EASL and AASLD. ${ }^{20-22}$ This staging system includes prognostic factors such as disease stage, number of the tumor lesion, portal vein invasion, liver function status, and patient performance status, based on results of cohort studies and clinical randomized trials. Therefore, BCLC is a favored classification system for prognosis allocation and treatment schedules in HCC patients. ${ }^{22}$ In this context, our findings are compatible with those reported in the literature, in terms of survival times and success rates of utilized treatment modalities.

Conventional cytotoxic chemotherapy agents are not used routinely for patients with advanced HCC as the efficacy of cytotoxic chemotherapy is mod- est in patients with these stages, and the duration of response is generally short. Therefore, we recommend and tend to use targeted therapeutic approaches rather than conventional cytotoxic chemotherapy for advanced HCC. Policies for drug reimbursement did not cover tyrosine kinase inhibitor therapy at that time as the first-line treatment in our country; therefore, medically appropriate patients with adequate hepatic function had been treated with cytotoxic systemic treatment as the first-line setting. Overall survival rates of patients who had been treated with cytotoxic agents seemed to be better than the tyrosine kinase inhibitor-treated group. The main reason that may explain the difference between survival rates is selection bias based on more medically appropriate patients being selected to receive cytotoxic therapies.

As observed in our study as well, patients with HCC generally have underlying cirrhosis, which was most often related to chronic viral infections like hepatitis B (HBV) or hepatitis C virus (HCV) infections. Due to cirrhotic liver status, patients who undergo therapy for HCC are at high risk for liver-related morbidity and mortality. The importance of cirrhotic status and its effect on the survival of HCC patients has been demonstrated by Poon et al. ${ }^{23}$, in this study, patients with both cirrhosis and large tumor lesion had significantly worse 5-year survival. Therefore, due to this strong relationship of liver cirrhosis status with the survival of HCC patients, cirrhosis is the most commonly used parameter of for the classification of HCC patients. 
International Journal of Hematology and Oncology

Table 3. The tumor treatment groups with their mean tumor sizes and proportion of cirrhosis.

\begin{tabular}{|c|c|c|c|}
\hline & Number of patients & The mean tumor size & Proportion of cirrhosis (\%) \\
\hline RFA or MWA & 9 & $2.5 \mathrm{~cm}$ & $66.7 \%$ \\
\hline TACE or TARE & 25 & $8.3 \mathrm{~cm}$ & \\
\hline Surgery treatment & 9 & $3.8 \mathrm{~cm}$ & $33.3 \%$ \\
\hline Systemic cytotoxic treatment & 27 & $10.4 \mathrm{~cm}$ & $55.6 \%$ \\
\hline Tyrosine Kinase inhibitor & 12 & $9.2 \mathrm{~cm}$ & $45.5 \%$ \\
\hline Best Supportive Care (BSC) & 3 & $14 \mathrm{~cm}$ & $75 \%$ \\
\hline
\end{tabular}

These classification systems are Okuda, cancer of the Liver Italian Program (CLIP), the BCLC, the Alberta classification, the Hong Kong Liver Cancer classification (HKLC), and etc. ${ }^{24}$ In our patient population, also, the effects of cirrhotic status on survival of patients have been confirmed.

HCC disease demonstrates a high tendency to invade the liver vasculature such as the main portal and hepatic veins or their branches and the inferior vena cava. ${ }^{25,26}$ These vascular invasions can be either macroscopic or microscopic type. Therefore, the PVTT in patients with hepatocellular cancer is not rare, and it is a very challenging feature of the disease. Because the PVTT has been reported as a negative prognostic factor and associated with much worse overall survival rates in HCC patients. ${ }^{27,28}$ Currently, in addition to various factors such as impaired liver reserve, large tumor size, tumor grade, and aggressive tumor biology, PVTT has been listed as a factor associated with worse prognosis. In our study as well, hepatocellular cancer patients with PVTT had poorer survival estimates than patients without PVTT, and our results are consistent with the results reported in the literature.

Although serum AFP level has not been included as a diagnostic criteria of HCC, it has been used as a valuable serum parameter for HCC treatment and taken into account as an important sign for the diagnosis. ${ }^{29}$ High level of serum AFP is associated with poor malignant characteristics of $\mathrm{HCC}$, such as larger tumor size, undifferentiated tumor subtype, diffuse infiltrative tumor type, and portal vein tumor thrombosis. ${ }^{30-34}$ Therefore, the serum AFP level has been known as an independent prognostic factor for the disease. In previous trial, the relationship between $400 \mathrm{ng} / \mathrm{ml}$ cutoff values of serum AFP level with survival has been reported and this threshold value was evaluated in our patient group 35. We found the level of AFP higher than $400 \mathrm{ng} /$ $\mathrm{ml}$ as a negative prognostic factor in our patient population as well. The patients in high AFP group had significantly shorter survival rates than the group with AFP level under $400 \mathrm{ng} / \mathrm{ml}$. This study contributed to utilize serum AFP cutoff level as a prognostic feature in $\mathrm{HCC}$ patients.

In addition to the retrospective nature of the trial, our study has some limitations. First, patient selection for treatment modalities is the most important confounding factor for the outcomes. Therefore, this should be taken into account when interpreting the results. Second, some patients have been treated with other treatment modalities when posttreatment progression developed, which could make it difficult to assess the exact effect of firstline treatment on survival. Therefore, this assessment method could be able to determine the OS of the patients, not disease-free survival for specific treatment modality. Another potential limitation of our study is to include just one institute HCC patient population with a limited number of cases. Finally, patient distribution among treatment groups was not even. Therefore, the comparisons between treatment modalities may have been influenced by the possible effects of uneven distribution.

In conclusion, this study reported the survival estimates of HCC patients with utilized first-line treatment modalities and tried to clarify the char- 
acteristics of them. Regarding the comparison of the results between treatment methods, if it is necessary to underline the important findings, the largest tumor size, serum AFP level, disease stage, hepatic function status (cirrhotic status), and presence or absence of micro-macro vascular invasion have been associated with patient survival. These important findings of the study should be taken into consideration in the design of future studies. Therefore, we think this study will be useful in choosing therapeutic strategies to treat HCC patients with different clinical features and will contribute to the development of more effective strategies against the disease, and thus improve the prognosis of hepatocellular carcinoma which still remains dismal.

\section{REFERENCES:}

1. De Angelis R, Sant M, Coleman MP, et al. Cancer survival in Europe 1999-2007 by country and age: results of EUROCARE- 5-a population-based study. Lancet Oncol 15: 23-34, 2014.

2. Mortality GBD, Causes of Death C. Global, regional, and national life expectancy, all-cause mortality, and causespecific mortality for 249 causes of death, 1980-2015: a systematic analysis for the Global Burden of Disease Study 2015. Lancet 388: 1459-1544, 2016.

3. Dogan E, Yalcin S, Koca D, Olmez A. Clinicopathological characteristics of hepatocellular carcinoma in Turkey. Asian Pac J Cancer Prev 13: 2985-2990, 2012.

4. Llovet JM, Bru C, Bruix J. Prognosis of hepatocellular carcinoma: the BCLC staging classification. Semin Liver Dis 19: 329-338, 1999.

5. Merle P, Blanc JF, Phelip JM, et al. Doxorubicin-loaded nanoparticles for patients with advanced hepatocellular carcinoma after sorafenib treatment failure (RELIVE): a phase 3 randomised controlled trial. Lancet Gastroenterol Hepatol 4: 454-465, 2019.

6. Mazzaferro V, Regalia E, Doci R, et al. Liver transplantation for the treatment of small hepatocellular carcinomas in patients with cirrhosis. N Engl J Med 334: 693-699, 1996.

7. Imamura H, Matsuyama $\mathrm{Y}$, Tanaka E, et al. Risk factors contributing to early and late phase intrahepatic recurrence of hepatocellular carcinoma after hepatectomy. J Hepatol 38: 200-207, 2003.

8. Llovet JM, Bruix J. Novel advancements in the management of hepatocellular carcinoma in 2008. J Hepatol 48 Suppl 1: S20-37, 2008.
9. Llovet JM, Real MI, Montana X, et al. Arterial embolisation or chemoembolisation versus symptomatic treatment in patients with unresectable hepatocellular carcinoma: a randomised controlled trial. Lancet 359: 1734-1739, 2002.

10. Lo CM, Ngan H, Tso WK, et al. Randomized controlled trial of transarterial lipiodol chemoembolization for unresectable hepatocellular carcinoma. Hepatology 35: 11641171, 2002.

11. Llovet JM, Bruix J. Systematic review of randomized trials for unresectable hepatocellular carcinoma: Chemoembolization improves survival. Hepatology 37: 429-442, 2003.

12. Ricke J, Bulla K, Kolligs F, et al. Safety and toxicity of radioembolization plus Sorafenib in advanced hepatocellular carcinoma: analysis of the European multicentre trial SORAMIC. Liver Int 35: 620-626, 2015.

13. Lopez PM, Villanueva A, Llovet JM. Systematic review: evidence-based management of hepatocellular carcinoma--an updated analysis of randomized controlled trials. Aliment Pharmacol Ther 23: 1535-1547, 2006.

14. Llovet JM, Ricci S, Mazzaferro V, et al. Sorafenib in advanced hepatocellular carcinoma. N Engl J Med 359: 378-390, 2008.

15. Kudo M, Finn RS, Qin S, et al. Lenvatinib versus sorafenib in first-line treatment of patients with unresectable hepatocellular carcinoma: a randomised phase 3 non-inferiority trial. Lancet 391: 1163-1173, 2018.

16. Hsu C-Y, Liu P-H, Lee YH, et al. Using serum $\alpha$-fetoprotein for prognostic prediction in patients with hepatocellular carcinoma: what is the most optimal cutoff? PloS one 2015; 10(3).

17. Bhoori S, Schiavo M, Russo A, Mazzaferro V. First-line treatment for hepatocellular carcinoma: resection or transplantation? Transplant Proc 39: 2271-2273, 2007.

18. Beard RE, Hanto DW, Gautam S, Miksad RA. A comparison of surgical outcomes for noncirrhotic and cirrhotic hepatocellular carcinoma patients in a Western institution. Surgery 154: 545-555, 2013.

19. Idilman I, Peynircioglu B, Cil BE, et al. Transarterial chemoembolization for treatment of hepatocellular carcinoma: A single center experience. Turk J Gastroenterol 24: 141 147, 2013.

20. Liver EAFTSOT. EASL-EORTC Clinical practice guidelines: management of hepatocellular carcinoma. J Hepatol 56: 908-943, 2012.

21. Bruix J, Sherman M. Management of hepatocellular carcinoma: an update. Hepatology 53: 1020-1022, 2011.

22. Llovet JM, Brú C, Bruix J. Prognosis of hepatocellular carcinoma: the BCLC staging classification. Semin liver Dis 19: 329-338,1999. 
23. Poon RT, Fan ST, Lo CM, et al. Long-term prognosis after resection of hepatocellular carcinoma associated with hepatitis B-related cirrhosis. J Clin Oncol 18: 1094-1101, 2000.

24. Tellapuri S, Sutphin PD, Beg MS, et al. Staging systems of hepatocellular carcinoma: A review. Indian J Gastroenterol 37: 481-491, 2018.

25. Roayaie S, Blume IN, Thung SN, et al. A system of classifying microvascular invasion to predict outcome after resection in patients with hepatocellular carcinoma. Gastroenterology 137: 850-855, 2009.

26. Yuan BH, Yuan WP, Li RH, et al. Propensity score-based comparison of hepatic resection and transarterial chemoembolization for patients with advanced hepatocellular carcinoma. Tumour Biol 37: 2435-2441, 2016.

27. Llovet JM, Bustamante J, Castells A, et al. Natural history of untreated nonsurgical hepatocellular carcinoma: rationale for the design and evaluation of therapeutic trials. Hepatology 29: 62-67, 1999.

28. Chan SL, Mo FK, Johnson PJ, et al. Prospective validation of the Chinese University Prognostic Index and comparison with other staging systems for hepatocellular carcinoma in an Asian population. J Gastroenterol Hepatol 26: 340-347, 2011.

29. Okuda K, Kotoda K, Obata H, et al. Clinical observations during a relatively early stage of hepatocellular carcinoma, with special reference to serum alpha-fetoprotein levels. Gastroenterology 69: 226-234, 1975.

30. Peng SY, Chen WJ, Lai PL, et al. High alpha-fetoprotein level correlates with high stage, early recurrence and poor prognosis of hepatocellular carcinoma: significance of hepatitis virus infection, age, p53 and beta-catenin mutations. Int J Cancer 112: 44-50, 2004.

31. Yokoo H, Kondo T, Fujii K, et al. Proteomic signature corresponding to alpha fetoprotein expression in liver cancer cells. Hepatology 40: 609-617, 2004.

32. Nomura F, Ohnishi K, Tanabe $Y$. Clinical features and prognosis of hepatocellular carcinoma with reference to serum alpha-fetoprotein levels. Analysis of 606 patients. Cancer 64: 1700-1707, 1989.
33. Tangkijvanich $\mathrm{P}$, Anukulkarnkusol $\mathrm{N}$, Suwangool $\mathrm{P}$, et al. Clinical characteristics and prognosis of hepatocellular carcinoma: analysis based on serum alpha-fetoprotein levels. J Clin Gastroenterol 31: 302-308, 2000.

34. Yamashita F, Tanaka M, Satomura S, Tanikawa K. Prognostic significance of Lens culinaris agglutinin A-reactive alpha-fetoprotein in small hepatocellular carcinomas. Gastroenterology 111: 996-1001, 1996.

35. Hsu CY, Liu PH, Lee YH, et al. Using serum alpha-fetoprotein for prognostic prediction in patients with hepatocellular carcinoma: what is the most optimal cutoff? PLoS One. 2015;10(3): e0118825.

\section{Correspondence:}

Dr. Sahin LACIN

Yeditepe Üniversitesi Tip Fakultesi

Tibbi Onkoloji Bilim Dali

34718 Kadiköy

ISTANBUL / TURKEY

Fax: (+90-216) 5785099

Tel: (+90-216) 5785000

e-mail: sahin81lacin@yahoo.com

\section{ORCIDs:}

Sahin Lacin:

0000-0002-8770-9842

Yusuf Karakas:

0000-0003-0205-4590

Omer Dizdar:

0000-0003-0911-9078

Saadettin Kilickap:

0000-0003-1637-7390

Manal M Hassan:

0000-0002-1362-7668

Lianchun Xiao:

0000-0003-0972-2766

Ahmed O. Kaseb:

0000-0002-2579-966X

Suayib Yalcin: 